\title{
The Procedural Syllabus and the Task Syllabus: How Similar, How Different?
}

\section{Sílabo procedimental y sílabo basado en tareas: semejanzas y diferencias*}

\author{
Sasan Baleghizadeh \\ s_baleghizadeh@sbu.ac.ir \\ Shahid Beheshti University, G.C., Tehran, Iran
}

The present paper aims to convince readers that the terms procedural and task syllabuses, often used interchangeably and synonymously, are fundamentally different from each other. After reviewing the underlying principles of these two syllabuses, it is contended that they both view pedagogic tasks as the point of departure in designing second/foreign language courses. Besides, neither of them is built on any pre-specified linguistic units such as structures, functions, notions, etc. In spite of this striking similarity, it is argued that these two syllabus types differ from each other in terms of task selection, task gradation, task implementation, and input characteristics.

Key words: Procedural syllabus, task-based language teaching, task syllabus.

Este artículo busca persuadir al lector de que los términos sílabo procedimental y sílabo basado en tareas, a menudo tratados como sinónimos, son fundamentalmente diferentes. Tras una revisión de los principios subyacentes en estos dos tipos de sílabos, se discute que ambos toman las tareas pedagógicas como punto de partida en el diseño de cursos para la enseñanza de lenguas. Además, ninguno de los dos se construye alrededor de unidades lingüísticas previamente especificadas como estructuras, funciones, nociones, etc. A pesar de esta similitud, se argumenta que los dos tipos de sílabos se diferencian en términos de la selección, secuencia e implementación de tareas y en las características de las muestras.

Palabras clave: enseñanza de lenguas mediante tareas, sílabo basado en tareas, sílabo procedimental.

* Received: February 12, 2015. Accepted: July 10, 2015.

How to cite this article (APA 6th ed.):

Baleghizadeh, S. (2015). The procedural syllabus and the task syllabus: How similar, how different? HOW, 22(2), 104-113.

This article is licensed under a Creative Commons Attribution-NonCommercial-NoDerivatives 4.0 International License. License Deed can be consulted at http://creativecommons.org/licenses/by-nc-nd/4.0/. 


\section{Introduction}

In recent years, the term task-based language teaching (TBLT) has become an often-heard and widely-used term in the literature of second/foreign language pedagogy (Ellis, 2003, 2013; Nunan, 2004; Robinson, 2011; Skehan, 2003; Willis \& Willis, 2007). TBLT is a perspective within the communicative approach, which views language learning as a process of doing a set of communicative tasks, "the purposes of which extend beyond the practice of language for its own sake" (Brown, 2001, p. 50). A brief review of the existing literature on TBLT (e.g., Ellis, 2013; Nunan, 1991, 2004; Willis \& Willis, 2007) reveals that this approach to language teaching is characterized by the following features:

- A heavy emphasis on learning to communicate through interaction in the target language.

- Using authentic materials as far as possible.

- Creating opportunities for learners to focus both on language and on the learning process.

- An attempt to link classroom learning with language activation outside the classroom.

The original impetus for TBLT comes from the celebrated Bangalore Project (Prabhu, 1987), which reacted against both the traditional form of English as a foreign language (EFL) used in India, and against the type of communicative language teaching practiced in Europe (Cook, 2001). Prabhu and his colleagues were perhaps among the first language teaching researchers who applied the principles of task-based instruction in an EFL project of nationwide scope in India. The syllabus type designed by Prabhu and his colleagues is called the procedural syllabus, which consisted of a set of pedagogic tasks. The procedural syllabus is often confused with the task syllabus, another recent development in language teaching. Despite the striking differences existing between these two syllabus types, the terms procedural and task syllabuses are sometimes used interchangeably (Richards, Platt, \& Platt, 1992; Richards \& Schmidt, 2010). Richards et al. (1992), for instance, use these two terms synonymously and describe them as "a syllabus which is organized around tasks, rather than in terms of grammar or vocabulary" (p. 373).

This paper aims to highlight the differences between procedural and task syllabuses and argue that despite the similarities between them, they are not one and the same thing.

\section{The Procedural Syllabus}

As mentioned earlier, the procedural syllabus is associated with the work of Prabhu and his colleagues in the Bangalore Project. Dissatisfied with the structural-oral-situational (S-O-S) method, which was widely practiced in the 1960s and 1970s in India, Prabhu decided to bring about a change in the traditional English language teaching (ELT) methodology of his 
country. Prabhu (1987) had observed that the students who had been taught English through S-O-S for several years at school were still unable to use it outside the class for communicative purposes.

As a result, Prabhu decided to introduce the principles of communicative language teaching in his well-known experimental project. Starting in 1979 and lasting for five years, this project involved eight classes of children ranging in age from 8 to 13. These students received their English instruction based on what Prabhu calls the procedural syllabus. This is an approach to language teaching which is learning-centered rather than learner-centered (White, 1988). The syllabus does not focus on any predetermined language content. Rather, class time is spent on doing a number of problem-solving tasks, which are intended to promote language acquisition. According to Prabhu (1987), language acquisition occurs when learners' attention is on meaning rather than on language forms. This is best achieved when learners are asked to do a number of meaning-focused activities, which result in natural communication in the classroom. It is, in fact, the firm conviction of Prabhu that optimal learning takes place when the target language is taught through communication and not simply for communication.

Communicative teaching in most Western thinking has been training for communication, which I claim involves one in some way or other in preselection; it is a kind of matching of notion and form. Whereas the Bangalore Project is teaching through communication; and therefore the very notion of communication is different. (Prabhu as cited in Long \& Crookes, 1993, p. 29)

Prabhu (1987) argues that teaching through communication takes place when learners are involved in doing a set of tasks. A task is an activity which gets learners to arrive at an outcome from given information through a process of thought, and which allows the teacher to control this process. As can be observed, this definition of task has a cognitive orientation, that is, it involves learners in a thinking process (Prabhu, 1987).

Each lesson in the procedural syllabus consists of a pre-task, a task, and a quick marking component. The task and the pre-task are two similar and parallel activities in that they require similar process of reasoning, and consist of similar question types, situations, sets of facts, and so forth. The pre-task, however, is a teacher-guided, whole-class activity which helps learners overcome the difficulties they might be faced with while doing the task. Thus the pre-task could be viewed as preparation for the task which is to follow.

The pre-task phase serves another function. It gives extrovert learners an opportunity to learn by making an attempt, and introvert learners the opportunity to learn without taking the risk of public failure. In other words, it is a confidence building activity which all learners can benefit from.

After the completion of the pre-task publicly, it is time for the students to do the task individually. They are allowed to do the task in pairs or in groups; however, this is neither 
recommended nor encouraged on the grounds that it is likely to result in fossilization. In Prabhu's (1987) opinion, it is necessary for learners' internal system to be firmed up by superior data; that is, input which comes from native or native-like sources.

Finally, there comes the third component of each lesson which is the marking stage. At this stage, the teacher checks the students' work and gives them some feedback on the basis of their accuracy in performing the task, not their accuracy in producing well-formed sentences.

Another point which should be mentioned about the tasks in the procedural syllabus is that they should be at a reasonable level of difficulty. In other words, students should face some challenge in doing the task. If the task is too easy, students may not take it seriously. If, on the other hand, it is too difficult they might be reluctant to give it a try. A task is reasonably challenging if approximately half of the students in the class are successful in doing approximately half of the task. This, in fact, is the formula by which teachers can grade and sequence the tasks of the subsequent lessons. The following is an example of a task used in the procedural syllabus, where students received a set of instructions to draw a simple picture:

a. Draw a line, from left to right.

b. Write $b$ at the right end of the line, and a at the left end.

c. Draw another line below ab.

d. Write $d$ at its left and $\mathrm{c}$ at its right end.

e. Join bd. (Prabhu, 1987, p. 33)

The last point worth noting about the procedural syllabus is related to the way language errors are corrected. In Prabhu's (1987) methodology, error correction is done incidentally rather than systematically. In other words, the teacher provides students with the correct form, but he or she does not attempt to focus on a linguistic form by teaching them the rules of grammar.

The methodological principles underlying the procedural syllabus were briefly introduced in this part of the article. Next, we shall look at the principles which guide the task syllabus.

\section{The Task Syllabus}

In the late 1980s and early 1990s language teaching scholars (Long \& Crookes, 1992; Nunan, 1988) began to question the efficiency of synthetic syllabuses which would break language into smaller units and then encourage learners to master it piece by piece. Wilkins (1976) originally defined this approach to language teaching as follows:

A synthetic language teaching strategy is one in which the different parts of language are taught separately and step by step so that acquisition is a process of gradual accumulation of parts until the whole structure has been built up. (p. 2) 
Initially, synthetic syllabuses were equated with grammatical syllabuses. However, it was argued later that situational, functional, notional, lexical, and even topical syllabuses are synthetic in that "syllabus content is ultimately based on an analysis of the language to be learned" (Long \& Crookes, 1992, p. 33). This approach to language teaching has often been criticized on the grounds that it is against the nature of language. Language is not something to be broken apart and then put together like different parts of a machine. Rather, it should be viewed as a living organism (Rutherford, 1987). This suggests a holistic approach to language teaching, which is manifested in recent proposals for task-based learning and task syllabuses (Ellis, 2003; Long \& Crookes, 1992; Willis \& Willis, 2007). Thus, dissatisfied with synthetic approaches, Long and Crookes, in a series of articles in the 1980s which resulted in their seminal paper, "Three approaches to task-based syllabus design" in 1992, laid the foundation for their task syllabus which views pedagogic tasks as the point of departure in the design process and as an appropriate tool in facilitating the teaching process. According to Nunan (2001), "a pedagogic task is a piece of classroom work having a beginning, middle, and an end, and a focus principally (although not exclusively) on meaning" (p. 315). Pedagogic tasks are usually designed with respect to target tasks which are often identified through a needs analysis process. Once the target tasks are identified, they are classified into target task types.

For example, in a course for trainee flight attendants, the serving of breakfast, lunch, dinner, and snacks and refreshments might be classified as serving food and beverages. Pedagogic tasks are then derived from the task types and sequenced to form the task-based syllabus (Long \& Crookes, 1992, p. 44).

Needless to say, it is the pedagogic tasks which are often worked on in the classroom, and they are graded on the basis of some criteria which will be briefly discussed later on.

The conclusion which can be drawn up to this point is that in both the procedural and the task syllabus, the content of the course is not determined by any pre-selected linguistic items such as structures, functions, notions, and so forth. Moreover, both of them use pedagogic tasks as the point of departure in designing language courses. For this reason, it might be falsely assumed that these two syllabus types are the same and the terms task and procedural syllabuses can be used interchangeably. However, there are some differences between these two syllabuses, which will be discussed below.

\section{The Procedural Syllabus Compared With the Task Syllabus}

There are four basic differences which distinguish the procedural syllabus from the task syllabus. These syllabuses differ in terms of (1) task selection, (2) task gradation, (3) task implementation, and (4) input characteristics.

1) Task selection. It was previously argued that both procedural and task syllabuses use pedagogic tasks as an appropriate vehicle for language teaching. In task syllabuses, the 
selection of tasks is guided by the results of a needs analysis process. In other words, pedagogic tasks are designed with reference to the real-world target tasks that learners are expected to do such as buying a plane ticket, renting an apartment, writing business letters, and so on.

This point, however, is not observed in the procedural syllabus. The tasks in the Bangalore Project were selected because of their intrinsic pedagogic merits, not because of their real-world target uses. Long and Crookes (1992) take this as a weak point of the procedural syllabus by arguing that "it is impossible for anyone to verify the appropriateness of particular pedagogic tasks for a given group of learners without objective evaluation criteria, one of which must surely be relevance to learner needs" (p. 37).

2) Task gradation. This is the second area in which the procedural and task syllabuses differ. Earlier it was mentioned that, in Prabhu's opinion, a good task is one which is at a reasonable level of difficulty. This was determined through the simple rule that if half of the learners in a class can do half of a task then its challenge is reasonable enough. It is on the basis of this criterion that tasks are graded and sequenced. As Long and Crookes (1992) observe, "[this] criterion for assessing difficulty is not a satisfactory solution, for it makes task achievement a norm-referenced issue, reveals nothing about what made a task easier than another, and thereby precludes any generalizations to new materials" (p. 37).

The advocates of task syllabuses, however, have some more objective criteria in determining task difficulty. Ellis (2003), for example, has offered a number of criteria based on which tasks can be sequenced. These factors are (a) input factors, including medium, code complexity, cognitive complexity, context dependency, and familiarity of information; (b) task conditions, including conditions relating to the negotiation of meaning, task demands, and the discourse mode required by the task; (c) factors related to the process of performing a task, including the type of reasoning needed; and (d) factors relating to task outcomes, including the medium, the scope, the discourse domain, and the complexity of outcome. These criteria are the ones which can partially guide course designers as well as teachers to sequence tasks. Obviously, a model of this sort allows a more practical space for task gradation than Prabhu's previously stated formula.

3) Task implementation. The third difference between the procedural and task syllabuses concerns how the tasks are implemented in each lesson. According to a widely-used framework (Willis, 1996), task-based teaching comprises three components: the pre-task, the task cycle, and the language focus (see Figure 1).

The function of the pre-task is to help students understand the objectives of the task. In this phase, the teacher can brainstorm ideas with the class, highlight useful words and phrases, give students preparation time to think how to do the task, and so on. This is quite different from the pre-task component of Prabhu's procedural syllabus, which involved students in a 
whole-class activity working on a task similar to what they were expected to do individually later on.

\begin{tabular}{c} 
PRE-TASK \\
Introduction to topic and task \\
\hline TASK CYCLE \\
Task $\rightarrow$ Planning $\rightarrow$ Report \\
\hline LANGUAGE FOCUS \\
Analysis and practice \\
\hline
\end{tabular}

Figure 1. The Willis (1996) Framework

In the second phase — the task cycle — students are encouraged to do the task in pairs or small groups and the teacher walks round and monitors their work. Students then prepare to tell the rest of the class how they did the task and what the outcome was. The teacher then asks some pairs to report to the whole class how they went about doing the task. Again, there is a difference between this stage compared to what occurs in Prabhu's methodology. It should be noted that students in the Bangalore Project were not encouraged to work in pairs or small groups. Moreover, they would not report the outcome of their work to the rest of the class.

Finally, in the language focus phase, students do some language-focused tasks based on the texts they have read or listened to. For example, they are asked to find words ending in $s$ or 's and say what the $s$ means. This differs from Prabhu's methodology, which places no emphasis on form-focused activities.

4) Input characteristics. The very last point mentioned in the previous heading, that is, form-focused instruction, brings us to the last difference between procedural and task syllabuses. In Prabhu's methodology, negative evidence seems to have no role in the process of language learning. For this reason, students in the Bangalore Project did not receive any feedback on the accuracy of the sentences they produced. Moreover, whenever they made an error, they were corrected incidentally not systematically. In other words, they were not provided with any explicit grammar instruction. In the task syllabus, however, there is an emphasis on form-focused instruction (Long \& Crookes, 1993). The term focus on form originally used by Long (1991) is defined as follows: "focus on form . . overtly draws students' attention to linguistic elements as they arise incidentally in lessons whose overriding focus is on meaning or communication" (pp. 45-46). Long insists that focus on form should not be confused with focus on forms, which is nothing but the structural syllabus. Thus focus 
on form is an attempt to get students conscious of linguistic code features in the context of a communicative classroom. These occasional shifts of attention to linguistic elements provide learners with negative evidence, which has been strongly supported in recent years (see for example Fotos \& Nassaji, 2007).

Table 1 summarizes the differences between these two syllabuses.

Table 1. Basic Differences Between Procedural and Task Syllabuses

\begin{tabular}{||l|l|l||}
\hline Syllabus & Procedural & Task \\
\hline Advocates & Prabhu & Long \& Crookes \\
\hline Task Selection & $\begin{array}{l}\text { Based on feedback obtained from } \\
\text { students' performance every session }\end{array}$ & Based on needs analysis \\
\hline Task Gradation & More or less subjective & More or less objective \\
\hline Task Implementation & pre-task, task, post-task & $\begin{array}{l}\text { pre-task, task, quick } \\
\text { marking }\end{array}$ \\
\hline Input Characteristics & no focus on form & focus on form \\
\hline
\end{tabular}

\section{Conclusion}

I began with a brief historical overview of TBLT. Two innovative approaches to syllabus design which take pedagogic tasks as the main tool of language instruction, that is, procedural and task syllabuses were described. The procedural syllabus is associated with the work of Prabhu (1987) and his colleagues in the Bangalore Project, who developed a version of the communicative approach with an emphasis on teaching learning through communication. The task syllabus, on the other hand, is associated with the work of Long and Crookes (1992). Both procedural and task syllabuses view pedagogic tasks as the main tool of language instruction. Moreover, neither of them is built on any pre-selected linguistic units such as structures, functions, notions, and so on. This, however, does not suggest that they are synonymous terms. They differ from each other in terms of task selection, task gradation, task implementation, and input characteristics. First, in the task syllabus, pedagogic tasks are selected on the basis of a needs-identification process, but this does not hold true for the procedural syllabus. Second, task gradation in the task syllabus is determined by more objective criteria. Third, the procedural syllabus favors teacher-fronted classes, while the task syllabus encourages pair work and group activities. Finally, the task syllabus welcomes the 
role of negative evidence (e.g., focus on form) in language classes. This, however, is not recommended in the procedural syllabus.

Drawing a conclusion about which of these two syllabuses is better for teaching foreign languages is not easy as it depends on a variety of factors such as the context of teaching, goal of instruction, proficiency level of the learners, etc. Although both are communicative syllabus types, the focus on the form phase of the task-based syllabus makes it more suitable for EFL contexts where accuracy is both needed and emphasized (Fotos, 2002). This is largely due to the fact that learners in most EFL contexts (e.g., Iran, South Korea, and Japan) are expected to take form-based English exams to be admitted to universities, so knowledge of grammatical forms is of paramount importance to these learners. In contrast, the procedural syllabus seems to be more suitable to learners in English as a second language (ESL) context where learners have ample opportunity to be exposed to English outside the classroom. The goal of instruction is also another determining factor. The procedural syllabus with little emphasis on systematic error correction and focus on form seems to be more suitable for those who want to learn English for survival purposes, while the task-based syllabus seems more ideal for those who wish to pursue academic goals. Finally, it seems that the procedural syllabus works better with elementary and pre-intermediate students, while the task-based syllabus is more compatible with intermediate students and above. This is mostly because beginning students need a course in which they can freely communicate removed from any form issues, while more advanced students need courses where there is a degree of focus on form through which they can produce accurate language.

\section{References}

Brown, H. D. (2001). Teaching by principles: An integrative approach to language pedagogy (2nd ed.). New York, NY: Longman.

Cook, V. (2001). Second language learning and language teaching (3rd ed.). London, UK: Arnold.

Ellis, R. (2003). Designing a task-based syllabus. RELC Journal, 34(1), 64-81. http://dx.doi.org/ $10.1177 / 003368820303400105$.

Ellis, R. (2013). Task-based language teaching: Responding to the critics. University of Sydney Papers in TESOL, 8(1), 1-27.

Fotos, S. (2002). Structure-based interactive tasks for the EFL grammar learner. In E. Hinkel \& S. Fotos (Eds.), New perspectives on grammar teaching in second language classrooms (pp. 137-154). New York, NY: Lawrence Erlbaum Associates.

Fotos, S., \& Nassaji, H. (2007). Form-focused instruction and teacher education. Oxford, UK: Oxford University Press.

Long, M. H. (1991). Focus on form: A design feature in language teaching methodology. In K. de Bot, R. B. Ginsberg, \& C. Kramsch (Eds.), Foreign language research in cross-cultural perspective (pp. 39-52). Amsterdam, NL: John Benjamins. http://dx.doi.org/10.1075/sibil.2.07lon. 
Long, M. H., \& Crookes, G. (1992). Three approaches to task-based syllabus design. TESOL Quarterly, 26(1), 27-56. http://dx.doi.org/10.2307/3587368.

Long, M. H., \& Crookes, G. (1993). Units of analysis in syllabus design: The case for task. In G. Crookes \& S. M. Gass (Eds.), Tasks in a pedagogical context: Integrating theory and practice (pp. 9-54). Clevedon, UK: Multilingual Matters.

Nunan, D. (1988). Syllabus design. Oxford, UK: Oxford University Press.

Nunan, D. (1991). Communicative tasks and the language curriculum. TESOL Quarterly, 25(2), 279-295. http://dx.doi.org/10.2307/3587464.

Nunan, D. (2001). Second language teaching and learning. Boston, MA: Heinle and Heinle Publishers.

Nunan, D. (2004). Task-based language teaching. Cambridge, UK: Cambridge University Press. http://dx.doi.org/10.1017/CBO9780511667336.

Prabhu, N. S. (1987). Second language pedagogy. Oxford, UK: Oxford University Press.

Richards, J. C., Platt, J., \& Platt, H. (1992). Longman dictionary of language teaching and applied linguistics (2nd ed.). London, UK: Longman.

Richards, J. C., \& Schmidt, R. (2010). Longman dictionary of language teaching and applied linguistics (4th ed.). Harlow, UK: Routledge.

Robinson, P. (2011). Task-based language learning: A review of issues. Language Learning, 61(Suppl. 1), 1-36. http://dx.doi.org/10.1111/j.1467-9922.2011.00641.x.

Rutherford, W. E. (1987). Second language grammar: Teaching and learning. London, UK: Longman.

Skehan, P. (2003). Task-based instruction. Language Teaching, 36(1), 1-14. http://dx.doi.org/ 10.1017/S026144480200188X.

White, R. V. (1988). The ELT curriculum: Design, innovation and management. Oxford, UK: Basil Blackwell.

Wilkins, D. (1976). Notional syllabuses. Oxford, UK: Oxford University Press.

Willis, J. (1996). A flexible framework for task-based learning. In J. Willis \& D. Willis (Eds.), Challenge and change (pp. 52-62). Oxford, UK: Macmillan Heinemann.

Willis, D., \& Willis, J. (2007). Doing task-based teaching. Oxford, UK: Oxford University Press.

\section{The Author}

Sasan Baleghizadeh is an Associate Professor of TEFL at Shahid Beheshti University (G.C.) in Tehran, Iran, where he teaches courses in applied linguistics, syllabus design, and materials development. He is interested in investigating the role of interaction in English language teaching and issues related to materials development. 